\title{
ENodicatio
Review \\ The Impact of Organising Six-Year-Old Children into Groups on their Collaboration in Achieving Goals
}

DOI: 10.15804/tner.2021.63.1.14

\begin{abstract}
This article is aimed at presenting the results from research. The aim of the research was to verify whether children organized in groups work more effectively in achieving a common goal.

The research method employed was that of a social experiment under natural conditions, with the parallel groups technique. The research group consisted of 100 six-year-old children over the course of two school years from two public kindergartens in the same location of a single town. The assumption was that the frequency of collaboration would be higher at the end of the school year for children organised by teachers into groups in order to achieve a common goal compared to children for whom this opportunity is intentionally not created by their teachers. The assumption was confirmed for the methods in which collaboration was manifested:

The assumption was confirmed for manifestations of cooperation: continuous, effective communication; helping a friend; praise, encouragement. The following was not confirmed: expression of one's own opinion/proposal; engagement in the achievement of a common goal.
\end{abstract}

Key words: collaboration, skill, manifestation, six-year-old child, method of implementation 


\section{Introduction}

Every individual is genetically equipped to exist, to get along, to achieve goals, and to cooperate with others. This article is aimed at presenting the results of research. The aim of the research was to verify whether children organized in groups work more effectively in achieving a common goal.

\section{Collaboration}

Collaboration is a 'jointly performed activity within the group and on the outside, subject to the acceptance of common goals'. As behaviour united by a common interest, it is a guarantee of world peace on a global scale (Kasíková, 2007, pp. 7-8). According to the UNESCO International Commission report 'Education for the Twenty-first Century', 'learning to do' and 'learning to live together' education pillars form the basis for this quality (1997, p. 52).

\section{Collaboration as a Principle of Czech Education}

Communication, cooperation and conflict management skills have a growing importance in the current concept of Czech education. Group work with functional collaboration between children is regarded as one of the most efficient educational forms. It leads to encouraging interaction and mutual assistance.

\section{Collaboration between Children in the Kindergarten}

Manifestations of collaboration develop only at the peer level, when children reach a similar level of social competence. Four- and five-year-old children need to perform activities with a friend, understood as "someone who wants what I want". Collaboration between six-year-old children is supported by communication, mutual agreement (Seifert, Hoffnung, 1994, pp. 128-131), and mutual assistance. The level of collaboration fully coincides with the child's zone of proximal development (Vygotsky, 2014, p. 212).

However, according to Piaget, socialised thinking habits develop at the age of 7-8 years and cannot even be affected by experience (Vygotsky, 2014, p. 56). Vygotsky mentions Stern who, when examining a child's patterns of thinking as formulated by Piaget (Piaget, Inhelderová, 1997, p. 7), highlights the impact of the social situation and the conditions in which the child is raised (2014, p. 87).

Specific activities and everyday unlimited contact in the kindergarten are crucial in establishing and developing collaboration between children; however, manifestations of collaboration are rarely learnt and practised. 
Collaboration is becoming an essential objective of pre-school education as set forth in the binding curriculum document (Smolíková et al., 2018, p. 25). It is a part of social, personal and communicative competence and serves as a guide in value orientation (Smolíková et al., 2018, p. 12).

\section{$\underline{\text { Research Methodology }}$}

We consider collaboration between six-year-old children to be a sociocultural phenomenon that can be realised in the contemporary Czech kindergarten, with its organisational structure based on the personality-oriented education model and on the current national curriculum. Our research on collaboration is based on the developmental socialisation paradigm.

Collaboration as a social skill can be defined by listing its manifestations in an individual's behaviour (Orpinas, Horne, 2006, p. 108). According to Kasíková, sharing, help, and support are manifested in achieving a common goal under voluntary collaboration (2007, p. 27).

The basic characteristics of a children's group were met in the research: the children consider themselves to be members of the group which features a common goal and interaction and mutual interdependence between the children (Gavora, 2005, p. 17). Mutual support, help, trust, and collaboration are mentioned by Johnson, Johnson, Holubec, Roy (1984, p. 14).

The following manifestations of collaboration were identified for six-year-old children in achieving a common goal in a group in the pre-research: achieving a common goal, continuous effective communication, helping a friend, praise, encouragement, expressing one's own opinion/proposal. This is not presumed to be an exhaustive list. Manifestations of collaboration can be implemented in different ways.

The research topic was: What is the impact of organising or not organising sixyear-old children into groups on their collaboration in achieving a common goal?

The research method employed was that of a social experiment under natural conditions with the parallel school class technique during two consecutive school years.

The research group consisted of 50 children in each school year - 25 children per class in two kindergarten buildings managed by one public school, both in the same location of a single town. The children were taught under the same educational program, with the same day-to-day organisational arrangement. The 
children turned six during the research; they had been attending the kindergarten for a full day for several years and were fully adapted.

The organisation of six-year-old children in achieving a common goal was an independent variable. In the experimental class (E), both teachers organised children into formal groups of five children to achieve the goal. In the control class $(\mathrm{K})$, the second pair of teachers did not organise children into groups to achieve the goal. The implementation methods for manifestations of collaboration (IMMCs) identified and evaluated for six-year-old children in the $\mathrm{E}$ and $\mathrm{K}$ class are dependent variables.

At the end of the children's final year of kindergarten, it was presumed that the frequency of IMMCs would be higher for those six-year-old children who were organised into groups by their teachers to achieve goals, compared to six-year-old children who were not organised into groups by their teachers. The interaction scheme for assessing results has been prepared using the social skills scheme (Pasch et al., 1998, p. 254) and Hunter's scheme (Gavora, 2005, p. 119).

The situations under evaluation were recorded on video in the classes. All legislative requirements were observed and ethical principles with regard to children were taken into consideration. This was field research.

\section{Research Results}

The IMMCs of six-year-old children, organised and unorganised into groups, when achieving the goal set by the teacher were the subject of evaluation. When evaluating the data under phase 1, the manifestations of collaboration between children identified in the pre-research appear in the video. The IMMCs were detected and the frequency thereof was recorded in the next phase.

Furthermore, the class E children's frequency of IMMCs and the class K children's frequency of IMMCs were evaluated and compared during each month of the research.

Subsequently, the class E children's frequency of IMMCs during the first observation (September 2017) was compared with the frequency of class E children's IMMCs during the last observation (May 2019). The results class K children's IMMCs during the first observation (September 2017) and under the last observation (May 2019) were similarly evaluated.

Finally, the results of the research on class E children's and class K children's IMMCs were compared using the Wilcoxon signed-rank test that is often used for 
paired comparison of small-scale data (Gauthier, Hawley, 2015; Barot et al., 2019, 2020). The significance was determined at $5 \%$.

The given implementation method for a certain manifestation of collaboration is illustrated by specific examples with regard to the class $\mathrm{E}$ children.

Manifestation of Collaboration - Engagement in Common Goal Achievement

The following implementation methods for the given manifestation of collaboration were identified for class $\mathrm{E}$ children:

M1/1 - [(M1) the first manifestation of collaboration; (/1) the first implementation method] Left the group after the teacher communicated the goal.

M1/2 - Only observes other children achieving the goal, left the group during the first half of the activity.

M1/3 - Does not pay attention to other children achieving the goal, left the group during the first half of the activity.

M1/4 - Developed an action to achieve the goal, then remained passive in the group for the entire duration of the activity.

M1/5 - Does not pay attention to other children achieving the goal, remained in the group longer than half of the activity.

M1/6 - Remained in the group for the entire duration of the activity and engaged in the achievement of the goal repeatedly, with breaks.

M1/7 - Remained in the group for the entire duration of the activity and engaged in the achievement of the goal.

Table 1. Engagement in the Achievement of a Common Goal

\begin{tabular}{lccccccccc}
\hline $\begin{array}{l}\text { Manifestation of } \\
\text { collaboration/ } \\
\begin{array}{l}\text { Implementation } \\
\text { method }\end{array}\end{array}$ & \multicolumn{2}{c}{$\mathbf{2}$ September } & \multicolumn{2}{c}{ January } & & May & \multicolumn{2}{c}{ Total } \\
\cline { 2 - 10 } & $\mathrm{E}$ & $\mathrm{K}$ & $\mathrm{E}$ & $\mathrm{K}$ & $\mathrm{E}$ & $\mathrm{K}$ & $\mathrm{E}$ & $\mathrm{K}$ \\
\hline $\mathrm{M} 1 / 1$ & 3 & 6 & 0 & 2 & 0 & 0 & 3 & 8 \\
\hline $\mathrm{M} 1 / 2$ & 2 & 1 & 2 & 2 & 0 & 3 & 4 & 6 \\
\hline $\mathrm{M} 1 / 3$ & 5 & 4 & 1 & 5 & 0 & 5 & 4 & 14 \\
\hline $\mathrm{M} 1 / 4$ & 1 & 2 & 1 & 5 & 0 & 1 & 2 & 8 \\
\hline $\mathrm{M} 1 / 5$ & 26 & 24 & 23 & 13 & 32 & 23 & 81 & 60 \\
\hline $\mathrm{M} 1 / 6$ & 10 & 2 & 13 & 13 & 18 & 5 & 41 & 20 \\
\hline $\mathrm{M} 1 / 7$ & 5 & 11 & 10 & 0 & 13 & 15 & 34 \\
\hline
\end{tabular}

Source: Own data 
Table 2. Wilcoxon Signed-Rank Test - Results

\begin{tabular}{lllll}
\hline \multicolumn{1}{c}{ Group } & \multicolumn{1}{c}{ E vs. K } & \multicolumn{1}{c}{ E vs. K } & \multicolumn{1}{c}{ E vs. $\mathbf{K}$} & \multicolumn{1}{c}{ Total E vs. K } \\
\hline Period & $09 / 2017,2018$ & $01 / 2018,2019$ & $05 / 2018,2019$ & $2017,2018,2019$ \\
\hline Wilcoxon & $p=0.865>0.05$ & $p=0.713>0.05$ & $p=0.833>0.05$ & $p=0.866>0.05$ \\
\cline { 2 - 5 } signed-rank & Criterion $W=15$ & Criterion $W=6$ & Criterion $W=11.5$ & Criterion $W=15$ \\
\cline { 2 - 5 } test & Effect size & Effect size & Effect size & Effect size \\
& 0.536 & 0.214 & 0.411 & 0.536 \\
\hline
\end{tabular}

The resulting $p$-value of the Wilcoxon signed-rank tests performed for each period, as shown in Table 2, shows that statistically significant differences between children of both classes in the implementation methods for any given manifestation of collaboration were not proven, not even in individual comparisons of $\mathrm{E}$ with $\mathrm{K}$ in September, January and May, and not even in the overall evaluation of $\mathrm{E}$ vs. K. The implementation methods for any given manifestation of collaboration between the children in class $\mathrm{E}$ were similar to that between the children in class $\mathrm{K}$.

Table 3. Comparison of Results

\begin{tabular}{lll}
\hline \multicolumn{1}{c}{ Group } & \multicolumn{1}{c}{ E 09 vs. E 05 } & \multicolumn{1}{c}{ K 09 vs. K 05 } \\
\hline Period & $2017 / 2019$ & 2017 / 2019 \\
\hline Wilcoxon signed-rank & \multicolumn{1}{c}{$p=0.866>0.05$} & $p=0.609>0.05$ \\
\cline { 2 - 3 } test & Criterion $W=15$ & Criterion $W=17$ \\
\cline { 2 - 3 } & Effect size & Effect size \\
& 0.536 & 0.607 \\
\hline
\end{tabular}

Table 3 shows a comparison of the results obtained with regard to the implementation methods for the given manifestation of collaboration in the first and last observation of the class $\mathrm{E}$ children vs. class K children. No statistically significant difference at the determined significance level was ascertained for the children in both classes in the evaluation thereof. The assumption was not confirmed.

\section{Manifestation of Collaboration - Continuous, Effective Communication}

Effective conduct in the group is not possible without the existence of a goal; however, the effectiveness of conduct is mediated through words. If used effectively, words facilitate collaboration (Vygotsky, 1970, p. 123). 
Class E children implemented this manifestation of collaboration in the following ways:

M2/1 - Verbally (only) suggested the next step to achieve the goal. Example: 'What if we put it in here ... and ... we'll see ...'

$\mathrm{M} 2 / 2$ - By taking action (non-verbally), took the next step to achieve the goal.

$\mathrm{M} 2 / 3$ - Verbally communicated and took the next step by taking action to achieve the goal. Example: 'I'll put it in here.'

M2/4 - Initiated communication, discussed achievement of the goal. Asked questions, invited others to answer. Example: 'Where does it fit? (flipping the card) Here?' Before taking any action, the child demanded verbal expressions from the others: 'Can I put it in here? Does it fit here?' Discussed achievement. Example: 'It (the fairy tale) doesn't continue like that, but...'

M2/5 - Communicated their experience achieving the goal (in the form of helping a friend). Example: 'When we were shopping for Christmas, we...'

M2/6 - Was passive in communication.

Table 4. Continuous, Effective Communication

\begin{tabular}{lccrrrrrrr}
\hline $\begin{array}{l}\text { Manifestation } \\
\text { of collaboration } \\
\text { / Implementa- } \\
\text { tion method }\end{array}$ & \multicolumn{2}{c}{$\mathbf{2 0 1 7 , 2 0 1 8}$} & \multicolumn{2}{c}{ September } & \multicolumn{2}{c}{ January } & \multicolumn{2}{c}{ May } & \multicolumn{2}{c}{ Total } \\
\cline { 2 - 11 } & $\begin{array}{c}\mathrm{E} \\
\text { (frequency) }\end{array}$ & $\mathrm{K}$ & $\mathrm{E}$ & $\mathrm{K}$ & $\mathrm{E}$ & $\mathrm{K}$ & $\mathrm{E}$ & $\mathrm{K}$ \\
\hline $\mathrm{M} 2 / 1$ & 24 & 26 & 21 & 6 & 14 & 6 & 59 & 38 \\
\hline $\mathrm{M} 2 / 2$ & 20 & 17 & 31 & 14 & 34 & 14 & 85 & 45 \\
\hline $\mathrm{M} 2 / 3$ & 16 & 13 & 15 & 9 & 42 & 13 & 73 & 35 \\
\hline $\mathrm{M} 2 / 4$ & 11 & 7 & 6 & 1 & 22 & 5 & 39 & 13 \\
\hline $\mathrm{M} 2 / 5$ & 8 & 3 & 14 & 6 & 22 & 8 & 44 & 17 \\
\hline $\mathrm{M} 2 / 6$ & 6 & 2 & 4 & 11 & 11 & 4 & 21 & 17 \\
\hline
\end{tabular}

Source: Own data

Table 5. Wilcoxon Signed-Rank Test - Results

\begin{tabular}{|c|c|c|c|c|}
\hline Group & E vs. $\mathrm{K}$ & Evs. $\mathrm{K}$ & E vs. $\mathrm{K}$ & Total E vs. K \\
\hline Period & $09 / 2017,2018$ & $01 / 2018,2019$ & $05 / 2018,2019$ & $2017,2018,2019$ \\
\hline \multirow{3}{*}{$\begin{array}{l}\text { Wilcoxon } \\
\text { signed- } \\
\text { rank test }\end{array}$} & $p=0.045^{\star}<0.05$ & $p=0.116>0.05$ & $p=0.028^{*}<0.05$ & $p=0.027^{\star}<0.05$ \\
\hline & Criterion $W=20$ & Criterion $W=18$ & Criterion $W=21$ & Criterion $W=21$ \\
\hline & $\begin{array}{l}\text { Effect size } \\
0.952\end{array}$ & $\begin{array}{l}\text { Effect size } \\
0.857\end{array}$ & $\begin{array}{l}\text { Effect size } \\
1.000\end{array}$ & $\begin{array}{l}\text { Effect size } \\
1.000\end{array}$ \\
\hline
\end{tabular}


The $p$-value shown in Table 5, supported by the higher test strength value, indicates statistically significant differences in the implementation methods for the given manifestation of collaboration between class $\mathrm{E}$ children and class $\mathrm{K}$ children at a significance level of 5\%. These differences were identified during the first observation in September and the last observation in May. The overall evaluation also indicates statistically significant differences between class E children compared to class $\mathrm{K}$ children. Continuous, effective mutual communication between children arises from the need to reach an agreement in achieving the goal. The assumption was confirmed.

Table 6. Comparison of Results

\begin{tabular}{lll}
\hline \multicolumn{1}{c}{ Group } & \multicolumn{1}{c}{ E 09 vs. E 05 } & \multicolumn{1}{c}{ K 09 vs. K 05 } \\
\hline Period & $2017 / 2019$ & $2017 / 2019$ \\
\hline Wilcoxon signed-rank & \multicolumn{1}{c}{$p=0.074>0.05$} & $p=0.588>0.05$ \\
\cline { 2 - 3 } test & Criterion $W=19$ & Criterion $W=9.5$ \\
\cline { 2 - 3 } & Effect size & Effect size \\
& 0.905 & 0.452 \\
\hline
\end{tabular}

However, when comparing the data for class E children from September and class E from May, no statistically significant differences were proven at the determined significance level. Similarly, no differences were proven when comparing the data for class $\mathrm{K}$ in September and class $\mathrm{K}$ in May.

\section{Manifestation of Collaboration - Helping a Friend (Verbally, by Action)}

Children are constantly encouraged to help friends in the kindergarten. The methods of implementation that six-year-old children are capable of are given in the following examples for class $\mathrm{E}$ children:

M3/1 - Verbally helped with the solution when asked. Example: 'Put it in here.; 'You must put that piece in here because...'

M3/2 - Helped by taking action when asked. Example: Finished painting a part of the object for a child who could not do it when asked to do so by the child.

M3/3 - Initiated help by taking action. Example: 'Wait a moment, I'll bring the white colour...'

The method by which the manifestation is implemented represents the highest level of mutual assistance between children. The assisting child analyses the other 
child's situation, concludes what their friend is missing and does not wait until (or whether) their friend asks for help; the child offers help on their own.

M3/4 - Takes a neutral attitude when asked. Example: 'Can you lend me your brush? You have the red colour in it now, I need it...' Following their friend's question, the child stiffly gazed and was unresponsive, which the questioning child evaluated as consent and acted accordingly.

No child refused to help their friend when asked for help.

Table 7. Helping a Friend (Verbal, by Action)

\begin{tabular}{lccccccccc}
\hline $\begin{array}{l}\text { Manifestation } \\
\text { of collaboration } \\
\text { / Method of im- } \\
\text { plementation }\end{array}$ & \multicolumn{2}{c}{ 2017, 2018 } & \multicolumn{2}{c}{ September } & \multicolumn{2}{c}{ January } & \multicolumn{2}{c}{ May } & \multicolumn{2}{c}{ Total } \\
\cline { 2 - 11 } (frequency) & $\mathrm{K}$ & $\mathrm{E}$ & $\mathrm{K}$ & $\mathrm{E}$ & $\mathrm{K}$ & $\mathrm{E}$ & $\mathrm{K}$ \\
\hline $\mathrm{M} 3 / 1$ & 2 & 2 & 3 & 2 & 12 & 2 & 17 & 6 \\
\hline $\mathrm{M} 3 / 2$ & 11 & 3 & 7 & 4 & 26 & 10 & 44 & 17 \\
\hline $\mathrm{M} 3 / 3$ & 7 & 3 & 13 & 8 & 30 & 10 & 50 & 21 \\
\hline $\mathrm{M} 3 / 4$ & 1 & 4 & 2 & 4 & 4 & 4 & 7 & 12 \\
\hline
\end{tabular}

Source: Own data

Due to the small number of comparable values obtained, the statistical evaluation was carried out using data from Table 8 below as well.

\section{Manifestation of Collaboration - Praise, Encouragement}

Piaget states that a child under the age of seven does not feel a desire to exert influence upon a partner. He states that a child thinks and speaks egocentrically, even if they are in a group with others (1970, p. 73).

However, the following implementation methods for this manifestation of collaboration were identified for six-year-old class $\mathrm{E}$ children in all four classes during the research:

M4/1- Praised a friend. Example: 'You remember a lot!'; 'Wow... it looks like you're taking a picture of it...; 'Um, that's a beautiful handbag...'

M4/2 - Encouraged a friend. Example: 'Yeah, it fits there!'; 'Try it!' And after a while: 'If it's wrong, we'll fix it.'

M4/3 - Expressed satisfaction from achieving the goal in front of others. Example: 'We've got a lot, haven't we?' 
Table 8. Praise, Encouragement

\begin{tabular}{|c|c|c|c|c|c|c|c|c|}
\hline \multirow{3}{*}{$\begin{array}{l}\text { Manifestation } \\
\text { of collaboration } \\
\text { / Method of im- } \\
\text { plementation }\end{array}$} & \multirow{2}{*}{\multicolumn{2}{|c|}{$\begin{array}{l}2017,2018 \\
\text { September }\end{array}$}} & \multirow{2}{*}{\multicolumn{2}{|c|}{$\begin{array}{c}2018,2019 \\
\text { January }\end{array}$}} & \multirow{2}{*}{\multicolumn{2}{|c|}{$\begin{array}{c}2018,2019 \\
\text { May }\end{array}$}} & \multirow{2}{*}{\multicolumn{2}{|c|}{$\begin{array}{c}2017,2018,2019 \\
\text { Total }\end{array}$}} \\
\hline & & & & & & & & \\
\hline & $\begin{array}{c}\mathrm{E} \\
\text { (frequency) }\end{array}$ & $\mathrm{K}$ & $\mathrm{E}$ & $\mathrm{K}$ & $\mathrm{E}$ & $\mathrm{K}$ & $\mathrm{E}$ & $\mathrm{K}$ \\
\hline M4/1 & 4 & 1 & 9 & 8 & 24 & 10 & 37 & 19 \\
\hline $\mathrm{M} 4 / 2$ & 10 & 5 & 12 & 10 & 27 & 14 & 49 & 29 \\
\hline M4/3 & 5 & 0 & 5 & 0 & 4 & 0 & 14 & 0 \\
\hline
\end{tabular}

Source: Own data

For the purposes of statistical evaluation, the data from Tables 7 and 8 were put together and assessed together. The resulting $\mathrm{p}$-value of the $\mathrm{t}$-tests performed are shown in Table 9.

Table 9. Wilcoxon Signed-Rank Test - Results

\begin{tabular}{lllll}
\hline \multicolumn{1}{c}{ Group } & \multicolumn{1}{c}{ E vs. $\mathrm{K}$} & \multicolumn{1}{c}{ E vs. K } & \multicolumn{1}{c}{ E vs. $\mathbf{K}$} & \multicolumn{1}{c}{ Total E vs. K } \\
\hline Period & $09 / 2017,2018$ & $01 / 2018,2019$ & $05 / 2018,2019$ & $2017,2018,2019$ \\
\hline Wilcoxon & $p=0.058>0.05$ & $p=0.074>0.05$ & $\boldsymbol{p}=\mathbf{0 . 0 2 8}{ }^{\star}<\mathbf{0 . 0 5}$ & $\boldsymbol{p}=\mathbf{0 . 0 2 7}{ }^{\star}<\mathbf{0 . 0 5}$ \\
\cline { 2 - 5 } signed- & Criterion $W=19.5$ & Criterion $W=24.5$ & Criterion $W=21$ & Criterion $W=27$ \\
\cline { 2 - 5 } rank test & Effect size & Effect size & Effect size & Effect size \\
& 0.696 & 0.875 & $\mathbf{0 . 7 5 0}$ & $\mathbf{0 . 9 6 4}$ \\
\hline
\end{tabular}

Values below the $5 \%$ significance level indicate statistically significant differences confirmed by higher test strength values. It is apparent that the differences in the implementation methods for this manifestation were proven for children in class E vs. K in the period May 2018 and 2019. The differences were also proven in the overall assessment of $\mathrm{E}$ vs. $\mathrm{K}$.

Table 10. Comparison of Results

\begin{tabular}{lll}
\hline \multicolumn{1}{c}{ Group } & \multicolumn{1}{c}{ E 09 vs. E 05 } & \multicolumn{1}{c}{ K 09 vs. K 05 } \\
\hline Period & $2017 / 2019$ & $2017 / 2019$ \\
\hline Wilcoxon signed-rank & \multicolumn{1}{c}{$\mathbf{p}=\mathbf{0 . 0 2 8} \boldsymbol{8}^{\star}<\mathbf{0 . 0 5}$} & $p=0.063>0.05$ \\
\cline { 2 - 3 } test & Criterion $W=27$ & Criterion $W=10$ \\
\cline { 2 - 3 } & Effect size & Effect size \\
& $\mathbf{0 . 9 6 4}$ & 0.357 \\
\hline
\end{tabular}


Statistically significant differences were proven for E class children, who improved the implementation methods for the given manifestations of collaboration. This can be attributed to the children's maturation overall and to their acquisition of experience in collaboration with other children.

\section{Manifestation of Collaboration - Expression of One's Own Opinion, Proposal}

The selected situations below show the implementation method for manifestation by class E children:

M5/1 - Verbally agrees with a friend's solution. Example: 'Yes, it fits here.'

M5/2 - Verbally disagrees, opposes. Example: 'You don't know the fairy tale well, that's not how the fairy tale continues!'

M5/3 - Disagrees, makes his or her own proposal. Example: 'That's not right. That's right (and continues drawing).'

M5/4 - Expressed their opinion and made their own suggestion. Example: 'We could draw a scalator (meaning an escalator) here.; 'There's a sky above the department store, but you can't see it, so you can't draw it there!'

M5/5 - Invited others to comment. Example: 'Shall I draw a cellar with cars? (meaning an underground garage)'; Does the shovel fit here or...there?' (showing).

Table 11. Expression of One's Own Opinion/Proposal

\begin{tabular}{|c|c|c|c|c|c|c|c|c|}
\hline \multirow{3}{*}{$\begin{array}{l}\text { Manifestation of } \\
\text { collaboration / } \\
\text { Method of im- } \\
\text { plementation }\end{array}$} & \multirow{2}{*}{\multicolumn{2}{|c|}{$\begin{array}{l}2017,2018 \\
\text { September }\end{array}$}} & \multirow{2}{*}{\multicolumn{2}{|c|}{$\begin{array}{c}2018,2019 \\
\text { January }\end{array}$}} & \multirow{2}{*}{\multicolumn{2}{|c|}{$\begin{array}{c}2018,2019 \\
\text { May }\end{array}$}} & \multirow{2}{*}{\multicolumn{2}{|c|}{$\frac{2017,2018,2019}{\text { Total }}$}} \\
\hline & & & & & & & & \\
\hline & $\begin{array}{c}\mathrm{E} \\
\text { (frequency) }\end{array}$ & $\mathrm{K}$ & $\mathrm{E}$ & $\mathrm{K}$ & $\mathrm{E}$ & K & $\mathrm{E}$ & $\mathrm{K}$ \\
\hline M5/1 & 1 & 3 & 5 & 3 & 7 & 3 & 13 & 9 \\
\hline $\mathrm{M} 5 / 2$ & 3 & 0 & 11 & 1 & 11 & 3 & 25 & 4 \\
\hline $\mathrm{M} 5 / 3$ & 3 & 3 & 5 & 6 & 17 & 9 & 25 & 18 \\
\hline M5/4 & 3 & 3 & 11 & 10 & 29 & 30 & 43 & 43 \\
\hline M5/5 & 5 & 2 & 7 & 5 & 10 & 5 & 22 & 12 \\
\hline
\end{tabular}

Source: Own data 
Table 12. Wilcoxon Signed-Rank Test - Results

\begin{tabular}{lllll}
\hline \multicolumn{1}{c}{ Group } & \multicolumn{1}{c}{ E vs. K } & \multicolumn{1}{c}{ E vs. K } & \multicolumn{1}{c}{ E vs. K } & \multicolumn{1}{c}{ Total E vs. K } \\
\hline Period & $09 / 2017,2018$ & $01 / 2018,2019$ & $05 / 2018,2019$ & $2017,2018,2019$ \\
\hline Wilcoxon & $p=0.276>0.05$ & $p=0.102>0.05$ & $p=0.078>0.05$ & $p=0.068>0.05$ \\
\cline { 2 - 5 } signed-rank & Criterion $W=5$ & Criterion $W=13.5$ & Criterion $W=14$ & Criterion $W=10$ \\
\cline { 2 - 5 } test & Effect size & Effect size & Effect size & Effect size \\
& 0.333 & 0.900 & 0.933 & 0.667 \\
\hline
\end{tabular}

It is apparent that significant differences in the results for Class $\mathrm{E}$ children compared to class $\mathrm{K}$ children were proven by the paired $\mathrm{t}$-test in the last observation in May 2018 and 2019.

Table 13. Comparison of Results

\begin{tabular}{lll}
\hline \multicolumn{1}{c}{ Group } & \multicolumn{1}{c}{ E 09 vs. E 05 } & \multicolumn{1}{c}{ K 09 vs. K 05 } \\
\hline Period & $2017 / 2019$ & $2017 / 2019$ \\
\hline Wilcoxon signed-rank & \multicolumn{1}{c}{$\mathbf{p}=\mathbf{0 . 0 4 3} \mathbf{3}^{\star}<\mathbf{0 . 0 5}$} & $p=0.066>0.05$ \\
\cline { 2 - 3 } test & Criterion $W=15$ & Criterion $W=10$ \\
\cline { 2 - 3 } & Effect size & Effect size \\
& $\mathbf{1 . 0 0 0}$ & 0.667 \\
\hline
\end{tabular}

It is apparent that the differences in the implementation methods for this manifestation have been proven only when comparing the results for class $\mathrm{E}$ children - the first observation vs. the last observation, i.e., for children who were organised into groups by their teachers to achieve the set goals. This was significantly supported by the test strength. However, most of the children quietly performed the task, listened, and observed.

\section{Conclusion}

Based on statistics, it has been confirmed that six-year-old children provided with conditions for collaboration to achieve a goal in groups during the school year were observed, at the end of the year, to display a higher frequency of IMMCs when achieving the common goal compared to children not intentionally provided with opportunities for collaboration to achieve a common goal in groups by their teachers. Some children displayed multiple ways to manifest collaboration; the 
frequency of implementation methods for certain manifestations is, therefore, not equal to the number of children in the class. The most obvious differences between the children in the classes regarding the implementation methods of manifestations of collaboration were: continuous, effective communication, helping a friend and praise, encouragement. The confirmation or rejection of the assumption was formulated in the evaluation of the individual implementation methods for each manifestation of collaboration.

The IMMCs mentioned in this article among six-year-old children organised into groups that were identified during the research are probably not exhaustive. Other IMMCs might be identified in other activities with other children achieving a common goal in groups. Since the research results indicate that this could be an effective form of education, it would be ideal to continue with the research.

Organising six-year-old children into groups to achieve a common goal is not a common practice in kindergarten. Teachers do not prefer having children work in groups to achieve a goal set within activities for various objective reasons. Methodological materials with educational activities elaborated in didactic categories and directly offering, requiring, or supporting the organisation of children into groups to achieve goals might contribute to a change in the situation.

\section{References}

Barot, T., Burgsteiner, H., \& Kolleritsch, W. (2020). Comparison of Discrete Autocorrelation Functions with Regards to Statistical Significance. In Advances in Intelligent Systems and Computing. Springer.

Barot, T., Krpec, R., \& Kubalcik, M. (2019). Applied Quadratic Programming with Principles of Statistical Paired Tests. In Advances in Intelligent Systems and Computing (Vol. 1047, pp. 278-287). Springer.

Gauthier, T.D. \& Hawley, M.E. (2015). Statistical Methods. In Introduction to Environmental Forensics: Third Edition (pp. 99-148). Elsevier Inc.

Gavora, Peter. (2005). Učitel a žáci v komunikaci. [Teacher and students in communication] Brno: Paido.

Johnson, D.W., Roger T.J., Holubec, E.J. \& Roy, P. (1984). Circles of Learning. Cooperation in the Classroom. North Washington St.: Alexandria.

Kasíková, h. (2007). Kooperativní učení a vyučování. Teoretické a praktické problémy. [Cooperative learning and teaching. Theoretical and practical problems]. Praha: Karolinum.

Orpinas, p. \& Horne, a. m. (2006). Bullying prevention. Washington: American Psychological Association.

Pasch, M. a kol. (2005). Teaching as decision making. Instructional Practices for the Successful Teacher. From the curriculum to the lesson. How to Work with curriculum. New York: Longman. 
Petty, G. (1994). Teaching Today: A Practical Guide. Cheltenham: Stanley Thornes.

Piaget, J., \& Inhelder, B. (1962). The Psychology of the Child. New York: Basic Books.

Seifert, K., \& Hoffnung, R. (1994). Child and adolescent development. New York: Boston.

(Learning is Hidden Wealth). 'Education for the 21 $1^{\text {st }}$ Century', UNESCO International Commission report. (1997). Praha: UK.

Smolíková, K, Opravilová, E., Havlínová, M., Bláhová, A. \& Krejčová, V. (2018). Rámcový vzdělávací program pro předškolní vzdělávání. [Framework Educational Programme for Pre-School Education] [online]. [cit. 2020-10-22]. (Available at: https://www.msmt. cz/vzdelavani/predskolni-vzdelavani/ramcovy-vzdelavaci-program-pro-predskolni-vzdelavani-3).

Vygotsky, L.S. (1962). Thought and language. London: The MIT Press Ltd. 